\title{
sciendo
}

CIVIL AND ENVIRONMENTAL ENGINEERING REPORTS

E-ISSN 2450-8594

CEER 2020; 30 (4): 0048-0055

DOI: $10.2478 /$ ceer-2020-0049

Original Research Article

\section{THE INFLUENCE OF CULTURAL-HISTORICAL DETERMINANTS ON FUNCTIONAL-SPATIAL DEVELOPMENT OF RURAL AREAS}

\author{
Hanna BORUCIŃSKA - BIEŃKOWSKA ${ }^{1}$ \\ University of Zielona Gora, Zielona Góra, Poland
}

\begin{abstract}
The article discusses selected issues regarding the influence of cultural-historical determinants on functional-spatial development of rural areas. Ecological, economic and social processes taking place in the last decades are examined in the context of the development of local self-governments and the rise of free market economy after Poland's socio-economic transformation. The process of intensive rural urbanization occurs especially in areas within the impact zone of big cities. It is caused by, i.a., human migration into rural areas and development of areas of business activation. The abovementioned tendencies that occur in the ecological, economic and social context have a significant impact on functional-spatial development. Expansion of housing developments and, in effect, expansion and development of necessary technical infrastructure gives rise to many problems concerning preservation of cultural heritage of the Polish countryside. The pursuit of sustainable development of rural areas is fundamental in regard to ruralist solutions as well as preservation of traditional rural architecture. Cultural-historical determinants play a considerable role in this pursuit, especially in the context of threats that stem from overurbanization of rural areas.
\end{abstract}

Keywords: cultural-historical determinants, economic, ecological and social processes

\footnotetext{
${ }^{1}$ Corresponding author: University of Zielona Gora, Faculty of Building, Architecture and Environmental Engineering, Department of Architecture and Urban Planning Z. Szafrana st 1, 65-516 Zielona Góra, Poland, e-mail: h.borucinska-bienkowska@aiu.uz.zgora.pl
} 


\section{INTRODUCTION}

The research focuses on selected conditions and factors with an influence on functional and spatial transformation of rural areas. The author discusses certain issues related to development of areas and housing functions in rural communes after 1989. In the last three decades (1990-2020), during the country's transformation, Poland's functional and spatial development has intensified. The social and economic transformations have boosted both metropolitan and rural area urbanization. The above-mentioned processes have been also stimulated, inter alia, by human migration and the related intensification of spatial development. The phenomenon has been particularly intense in the areas of communes within the impact zone of large cities. It has played a significant role in urbanization, especially in rural areas. [2]

Jerzy Wiklina and Iwona Nurzyńska have authored a report on the state of the countryside, published in 2016 [11]. The report shows that $10 \%$ of the rural population works in agriculture. This process will change, as in Poland the highest percentage of the population lives off agriculture compared to the corresponding data in Western Europe. The employment rate in agriculture is constantly decreasing. After 1989, in rural areas, especially located in the impact zone of large cities, the phenomenon of rural depopulation has been reversed. It is influenced, inter alia, by the suburbanization process taking place in metropolitan areas. GUS (Statistics Poland) data from December 31, 2016 showed that 15.3 million people lived in rural areas. Compared to 2006, the rural population increased by 546.900 . In cities, in the same period, population decreased by 239.400 . The rural population share in the total population increased by $1.1 \%$ to $39.8 \%$. The increase in the rural population was also shaped by a positive birth rate, but the decisive factor was the positive net migration. On the other hand, the researchers in the field: M. Kłodziński [5], K. Koreleski [6], M. Adamowicz [1] emphasize the multifunctionality of rural areas as a way to ensure their sustainable development.

\section{CHARACTERTISTICS OF THE CURRENT STATE OF THE CULTURAL-HISTORICAL ENVIRONMENT. RESEARCH SUBJECT - LUBASZ VILLAGE}

The village of Lubasz is situated by Duże lake, in Lubasz commune, in CzarnkówTrzcianka county, in Wielkopolskie province. In the north, Lubasz commune borders the town of Czarnków and the commune of Czarnków; in the east, it borders Połajewo commune; in the west, it borders Wielun commune; and in the south, it borders two communes: of Wronki and of Obrzycko (Szamotuły county). 
In the north and west, the commune is surrounded by woods and forests. [3] The area of the village houses an area of protected landscape (Polish: OChK) and numerous natural monuments. OChK "Noteć Forest" (Polish: Puszcza Notecka) covers the central and middle part of the village, and it is a crucial element in the ecological system of international importance. It joins Noteć Valley with Warta Valley together forming ecological corridors. The area of OChK "Noteć Valley" is where arable land occurs, as well as woods of the Czarnków moraine, Duże lake and the Lubaski Canal. The abovementioned OChK is a vital nature refuge for birds, and is a stop on the route of their migration. [4]

\subsection{Selected Cultural-Historical Determinants}

The characteristics of settlement traces in the area of the village are typical of this part of the region of Greater Poland (Polish: Wielkopolska). Single artefacts and settlement traces date back to the Neolithic. [3] Remnants of a cone-shaped gord that are situated in the court park in the north-east part of the village are evidence of the early medieval settlement in the area of the present village of Lubasz. It is a burrow in the shape of a cone surrounded by a ring of wall with traces of a moss. Intensive development of the village of Lubasz took place in the 18th century. The palace of the Miaskowski family is situated in the southern part of an 18th-century park based on the concept of the landscape park, with an abundant stand of trees and numerous natural monuments. The L-shaped classicist building was erected for the family of Wojciech Miaskowski, a provincial governor of Kalisz, in the mid-18th century in place of the former 16th-century wooden manor. The dates of the manor's (1546) and the palace's (1756) erection can be seen over the arcade supported by ten columns, as well as the date of the last redevelopment carried out by the Szułdrzyński family in 1911. The park also houses a classicist outbuilding dated back to the first half of the 19th century.

Another vital historic building is a late Baroque cruciform church with two towers, erected in mid-1700s (1750-1761). Inside, the church boasts polychromies made by Wacław Tarczyński; the altar houses a painting of the Mother of God of Lubasz. The nearby churchyard is the burial place of participants of the Greater Poland Uprising, i.a. one of its leaders Włodzimierz Raczyński, as well as Bolesław Paszyński, a highly acclaimed forester. In the vicinity of the church is an English Gothic bell tower, a rectangular structure from 1856. The historic ruralist layout is based on the former north-west route constituting the main historic compositional axis of the village of Lubasz. The ruralist layout has retained the trace of the former market square of the village. The complex of the Birth of Saint Mary Church with the churchyard and the manor complex with the park is complemented by historic development along the local roads. The village's beautiful layout is spatially clear, well preserved and is under conservation. 
In the area of the village of Lubasz, the conservation programme covers i.a. the 18th-century palace, the palace outbuilding dated back to the mid-1800s, the historic court park spanning an area of 30.7 ha, an archaeological site - a coneshaped gord, and the Birth of St Mary Church with a parish house from the mid1800s, a Catholic churchyard and a Jewish graveyard. [8] Among others, the railway station, a 19th-century distillery, a 1920s post office, and buildings situated at: 34 Chrobrego Street, 6 Kościelna Street, 3 Szkolna Street, 2 Szamotulska Street, 5 Stajkowskiej Street, 11 Wiejska Street, 7 Zielona Street were entered into the register of the provincial conservator of historic and cultural heritage. [12]

\subsection{Quality of the Cultural-Historical Environment - Opportunities and Threats}

Cultural-historical environment of Lubasz village is a valuable part of Greater Poland's heritage, which should be understood as urban and ruralist layouts, historic building developments, single architectural and civil structures, industrial and technical facilities, park and garden complexes, cemeteries, and archaeological monuments. Lubasz village has historic ruralist layouts with building complexes, single buildings, and forms of designed greenery situated in the layout of historic divisions of property. The village has retained the old functional-spatial layout with two historic complexes: a church complex, i.e. the Birth of St. Mary Church with a gate and a masonry bell tower, and a palace-park system with a classicist palace. In the park, there is a classicist outbuilding from the first half of the 19th century. The abovementioned buildings are preserved in a clear functional-spatial layout against the historic ruralist one.

The issues of renewal, modernization, renovation and revitalization play and important role in shaping functional-spatial policy of the countryside. Plans involving preservation and restoration of the aesthetic and cultural values of the past, as well as material objects, whole building complexes and ruralist layouts were incorporated into spatial and land-use planning at the beginning of the 1990s. At the time of the country's transformation, they played a significant part in shaping awareness of self-governmental authorities and local communities in terms of the value of tangible environment of the past. It should be highlighted that for the tasks mentioned above, it is also necessary to outline procedures for public communication and the scope of co-creation, as well as co-responsibility for programmes of local communities.

Planned and designed functional-spatial solutions should sanction the current layout, while new solutions should not interfere in the structure of ruralist arrangements, buildings and other structures under legal protection. Thy constitute a value of historic heritage at both regional and national level. Historic 
buildings are threatened by i.a. their poor technical state, unregulated property ownership, insufficient funds for their renewal, restoration, refurbishment and modernization.

\section{DIAGNOSIS OF THE STATE OF CULTURAL-HISTORICAL ENVIRONMENT}

\subsection{Assessment of the State of Cultural-Historical Environment}

The area of Lubasz village boasts significant historic, cultural and environmental values partially under legal protection, which promotes a relatively good state of its natural environment. Most of the landscape values have retained their natural character. The greenery in historic parks and graveyards is well maintained. Resources of tangible heritage constitute the village's great asset. Legal protection helps preserve ruralist layouts, building complexes, single buildings and structures. The former functional-spatial layout with two historic complexes, i.e. the church complex of the Birth of St Mary Church with a gate and a masonry bell-house dating back to 1856 , and the palace-park complex with a classicist palace are cultural-historical heritage of the village, the county and the province. The park also houses i.a. a classicist outbuilding from the first half of the 19th century. The abovementioned buildings and layouts are preserved in a clear functional-spatial system.

\subsection{Forecast of Changes of the Cultural-Historical Environment}

Legal protection of elements of cultural-historical environment and natural areas reflects the objective of self-governments and local communities to preserve tangible cultural heritage and natural environment. It also renders it possible to forecast further sustainable development of the countryside. Attractive natural environment, Areas of Protected Landscape, well-preserved ruralist layouts and historic monuments constitute an integrated functional-spatial structure.

Anthropopressure is a factor that affect rural environment. Sustainable functionalspatial development of the countryside will promote preservation of historic, cultural and environmental heritage in a good state for generations to come. Functional-spatial transformation of the countryside is affected by ecological, economic and social factors and determinants. 


\section{FORECAST FOR THE CULTURAL-HISTORICAL STATE}

Protection of cultural-historical environment is intrinsically intertwined with environmental protection. Only correct ecological, economic and social relations can guarantee sustainable development of functional zones.

The village of Lubasz has ruralist layouts with building developments and single buildings under legal protection. Old functional-spatial layouts with two historic complexes: the Birth of St Mary Church complex with a gate and a masonry bell tower as well as the palace-park complex with a classicist palace are preserved here.

Local workshops and production-commercial facilities do not pose a threat to the natural environment as they do not emit substances that exceed permissible standards. The problem of emission of harmful substances into the air occurs, on few occasions, in the autumn-winter season when individual households generate such emissions.

The area of Duże lake inclines to create marshes and swamps with vegetation characteristic of this type of habitats. The lake and the wetlands are fed by watercourses, rainfall and melting snow which carry surface pollutants, including pollutants from arable land. Functional-spatial development of Lubasz depends both on determinants of the natural environment and cultural-historical environment along with economic and social determinants.

\section{CONCLUSIONS}

The existing and planned functional-spatial land development of the area needs first of all:

1. preservation of the existing areas and objects under legal protection,

2. introduction of plans for revitalization, renovation and modernization for the areas and buildings of historical and cultural importance,

3. equipment of all invested areas with relevant pro-ecological technical infrastructure,

4. introduction of pro-ecological low-emission heating energy sources for all users,

5. restrictions on location of new business activity areas and productioncommercial facilities in the areas of historic housing development under legal protection,

6. uarantee of correct waste management with special regard to waste resulting from business activities,

7. land remediation of all areas that require remediation. 
The above-mentioned conclusions cover ecological issues related to modernization, renovation and often revitalization of degraded facilities and areas. They primarily consist in implementing environmentally friendly technical infrastructure solutions. They also contain economic issues that very often determine the possibilities of preserving and maintaining historic objects. The lack of sufficient funds often determines the scale and pace of works carried out in historic buildings. Also, local communities' and local governments' awareness of the value of material and non-material cultural heritage may contribute to the preservation of rural systems and historic objects for the next generations.

\section{REFERENCES}

1. Adamowicz, M 2009. Wielofunkcyjne gospodarstwa rolne jako podmiot w rozwoju wsi i rolnictwa (English: A multifunctional agricultural holding as an agent in the development of rural areas and farming), [in:] Wiejskie gospodarstwa domowe $\mathrm{w}$ obliczu problemów transformacji, integracji i globalizacji (English: Rural household in the face of the issues of transformation, integration and globalization), Prace Naukowe KPAiM no. 33, Wydawnictwo SGGW, Warsaw.

2. Borucińska-Bieńkowska, H 2017. Proces urbanizacji terenów wiejskich gmin powiatu poznańskiego (English: Urbanization process of rural areas of the county of Poznań), Politechnika Śląska, Gliwice.

3. Łęcki, W [ed.] 2004. Wielkopolska nasza kraina (English: Greater Poland Our Land), Wydawnictwo S.A. Kurpisz, Poznań.

4. Karwacka, G, Kijowska, J, Kijowski, A and Żynda, S 2006. Komentarz do map sozologicznych - arkusz Rosko, Obrzycko, Czarnków, Wronki (English: Commentary to environmental science maps - sheet Rosko, Obrzycko, Czarnków, Wronki), UAM, Poznań.

5. Kożuchowski, K 2005. Walory przyrodnicze w turystyce i rekreacji (English: Environmental values in tourism and recreation), Wydawnictwo Kurpisz, Poznań.

6. Kłodziński, M 1996. Wielofunkcyjny rozwój terenów wiejskich $w$ Polsce $i w$ krajach Unii Europejskiej (English: Multifunctional development of rural areas in Poland and EU countries), Wydawnictwo SGGW, Warsaw.

7. Koreleski, K 1998. Rozwój wielofunkcyjny jako koncepcja aktywizacji gospodarczej wsi i rolnictwa (English: Multifunctional development as a concept of economic activation of the countryside and agriculture), Zeszyt Naukowy AR, issue 59, Kraków.

8. Studium uwarunkowań i kierunków zagospodarowania przestrzennego gminy Lubasz zatwierdzone Uchwałą Rady Gminy Lubasz nr IV/38/19 z dnia 25 lutego 2019 r. (English: A study on spatial planning determinants and 
THE INFLUENCE OF CULTURAL-HISTORICAL DETERMINANTS ON FUNCTIONAL- 55 SPATIAL DEVELOPMENT OF RURAL AREAS

directions of the Lubasz commune approved by the Resolution of the Council of the Lubasz Commune no. IV/38/19 of 25 February 2019).

9. Ustawa z dnia 16 kwietnia 2004 r. o ochronie przyrody Dz.U. Nr 92 z 2004 poz.880 (English: Act of 16 April 2004 on environmental protection, Journal of Laws No. 92 of 2004, item 880).

10. Ustawa z dnia 23 lipca 2003 o ochronie zabytków i opiece nad zabytkami Dz. U. Nr 162 z 2003 r. poz. 1568 (English: Act of 23 July 2003 on protection and care of tangible cultural heritage, Journal of Laws No. 162 of 2003, item 1568).

11. Wiklina, J and Nurzyńska, I 2016. Polska wieś 2016. Raport o stanie wsi (English: Rural Poland 2016. The report on the state of rural areas), Wydawnictwo naukowe Scholar, Warsaw.

12. A list of building structures included in a register or other records run by the Provincial Conservator of Cultural and Historic Heritage.

Editor received the manuscript: 07.07.2020 